Ciência e Natura, Santa Maria, v. 37 n. 3 esp. 2015, p. 36-50

Revista do Centro de Ciências Naturais e Exatas - UFSM

ISSN impressa: 0100-8307 ISSN on-line: 2179-460X

\title{
ciênciaenatura
}

\section{Women and Rural Development in Iran: Analysis of the effect of Socio- Economic changes on women' work in agriculture.}

\author{
Fazileh Dadvar-Khani ${ }^{1}$, Shahla Choobchian²
}

${ }^{1}$ Associate professor, Department of Geography and Rural planning, university of Tehran and Member of The center of Excellent in rural studies and planning ${ }^{2}$ Assistant Professor, Department of Agricultural Extension and Education, Tarbiat Modares University, Tehran, Iran

\begin{abstract}
There are a number of observable and marked changes in the economic, social, and also cultural status of women's life in rural areas. This study investigates factors which influence economic participation of women in north of Iran's rural areas. The influence of government development policy, such as education and Income generating on rural women was sought and investigated in this study. This study particularly focuses on 3 important factors such as "family income", "women's education " and "economic class of family" which represent economic, social and cultural status. The descriptive survey method has been applied in this research. The statistical population was 108682 households, from which 131 families were randomly selected. Data has gathered through questionnaires. The results suggest that However, rural development strategies would solve one problem for the women and create another. This paper argues that although rural development may have been beneficial to women and the society as a whole, it has implications for gender roles that go beyond the purview of women's empowerment. These symptoms reflect a lack of structured development strategy to create new opportunities in these areas. As a result, despite the increasing in women education and family income there is a high rate of unemployment, because the current development policy clearly has failed to introduce new opportunities for women in labor market.
\end{abstract} Iran.

Keywords: Rural women, women and agriculture, women and rural development, women in third word, rural women's education, 


\section{Introduction}

G lobally, rural areas have been subjected in recent decades to change taking place at an unprecedented place and with dramatic consequences for reshaping the rural. These changes are important to women's life in two ways. First, they extend women's ability, by increasing their access to higher level of education. Second, due to increasing in family income, they challenge rural lifestyle with replacing the family labour by paid labour or machine and narrow the work opportunity and participation in agriculture for women. Rural women's participation in the agricultural activities has been the focus of intensive debates by most international forums in the past years. Among forums that have recognized the plight of Third World's women's participation in the development process are the 1995 Nairobi Forward Looking Strategies for the Advancement of Women held in Kenya, the 1995, The Beijing Declaration, and the United Nations Development Fund for Women (2000). According to the philosophy of these forums, each member state should promote women's economic independence, which includes the

creation of employment, access to resources and credit, the eradication of the persistent and increasing burden of poverty, malnutrition, poor health and illiteracy on women. (Kongolo, M. and Bamgose, O. O. (2002). Also The problem of underestimating of women's work in labour force statistics and national income accounts has been pointed out repeatedly since 1970s (Boseroup 1970, Weinerman and lattes 1981, Beneria 1982, Dixon-Mueller and Anker 1988). This underestimation has been observed particularly in case of rural labour market, that women involved in three general areas of activity 1) Informal paid work, mostly in subsistence production 2) Domestic production and related task as a family worker 3 ) exchanged labour. Even by accepted definitions of labour force, there has been tendency to ignore the importance of female participation in rural labour market. This situation when accompany with new changes in rural areas such as women's access to higher education, increasing in rural household income and landownership has led to excluded of women from rural labour market. Also in other third world countries, such as Africa there is overwhelming evidence of development policies and projects formulated bypassing the involvement of rural women in most rural areas (Hunger Project, 2000). So women who actively contributed to every stage in production cannot benefit from the opportunities brought by development, and are among those who are most affected by the disadvantages caused by poverty and underdevelopments. In countries such as Iran, where unemployment is widespread and where education is high among women the problem of women's unemployment and their participation in work life draw considerable attention.

Many small towns in Iran are facing serious economic, social and environmental problems. For

many years, a number of rural areas have been undergoing population loss despite of increasing in services (Dadvar-Khani, 2012). According to the 2013 census, the population of Iran was 77. 45 million (31. $5 \%$ lived in rural areas and $68.5 \%$ lived in urban areas.). It makes rural development as a serious tool to promote national development.

Development is generally concerned with the enhancement of an individual's ability to shape their lives (Sen, 1999). According to Stiglitz (1999), development can be regarded as a transformation of society, a movement from traditional ways of thinking and traditional methods of production to more modern 
approaches. In other words, development must improve all aspects of people's lives. This is what Servaes (1999) calls multi-dimensional development (Ignatius A. Madu, 2010). According to Olopoenia (1983) and Pradip (1984), development is not an isolated activity, for it implies a progress from a lower state to a higher and preferred one. Development is a process by which people are awakened to opportunities within their reach. Development, therefore, starts with people and progresses through them (Seer, 1981; Gwanya, 1989). This is the reason, that rural woman should be involved in ongoing development initiatives. Hugger believes that, they are the most marginalized group in terms of their needs, while being the people who produce almost $80 \%$ of the food consumed in most of Africa's rural areas (Hunger Project, 1999).

Rural development in general is used to denote the actions and initiatives taken to improve the standard of living in non-urban neighbourhoods, countryside, and remote villages. These communities can be exemplified with a low ratio of inhabitants to open space. Agricultural activities may be prominent in this case whereas economic activities would relate to the primary sector, production of foodstuffs and raw materials. Rural development is mostly aimed at the social and economic development of the areas in which they work. These programs are usually Top-down from the local or regional authorities, regional development agencies, NGO's, national governments or international development organizations. But, local populations can also bring about endogenous initiatives for development.

This research seeks to show the influence of such dynamics upon women's livelihood and their participation in farming activities. So it going to show that although changes in rural areas led to some prosperities such as increasing in education level or increasing of the family's income but these changes do not necessarily led to better situation for women.

Iran is a rich country in mineral and power resources, although agriculture is an important

sector as well. About $9 \%$ of the GDP comes from agriculture (statistical center of Iran 2006).

In Iran due to agricultural mechanization, participation of women in agricultural works is decreasing dramatically (from 14. 68 in 1996 to 11. 58 in 2006). The researches indicate that women due to social, cultural and legal factors not only have limited access to different sectors of National economy, but also they are suffering from different kind of discrimination in the market, for example the main activities of women in the industrial sector are concentrated on three subtype of textiles, clothing and food industries while other industrial sectors are dominated mostly by men. See table (1)

Table 1: Women's participation in different kind of economic sectors

\begin{tabular}{|c|c|c|c|c|c|}
\hline \multicolumn{2}{|c|}{ Variables } & \multicolumn{2}{c|}{1996} & \multicolumn{2}{c|}{2006} \\
\cline { 3 - 6 } & & Rural & Total & Rural & Total \\
\hline \multirow{3}{*}{ Economic Sectors } & Agriculture & 30.82 & 14.68 & 43.24 & 12.3 \\
\cline { 2 - 6 } & Industry & 47.92 & 32.93 & 35.95 & 17.84 \\
\cline { 2 - 6 } & Services & 16.9 & 47.43 & 20.79 & 69.84 \\
\hline \multirow{2}{*}{ Women In Paid Work } & Public & 15.45 & 42.16 & 14.24 & 39.74 \\
\cline { 2 - 6 } & Private & 19.19 & 52.06 & 81.57 & 57.19 \\
\hline Women In Unpaid Work & Women In Self- Employed & 28.53 & 19.64 & 34.12 & 23.23 \\
\hline
\end{tabular}

Source:Iran General Census of Population and Housing 2006

The majority of women working in rural areas are at the status of unpaid family worker. The increase of women's employment is highly dependent on economic development and requires new investments and creation of new areas of work. The distribution of women in the 
workforce by sector (Table. 1) reveals that 43 . $24 \%$ of women working in agriculture in 2006, while it was 14. 68 in 1996. However, in the selfemployed workforce this ratio is 23. 23 for 2006 and 19. 64 for 1996. Most of these jobs are in unpaid family agriculture, as in rural area, it reaches to 34.12 in 2006.

The low ratio of women who work as "employer" in both the agricultural and nonagricultural sector is noteworthy. It provides evidence to the fact that women almost never are entrepreneurs in society. Another phenomenon to note here is that in both work life and sociocultural life rural women, who intensively participate in the (agricultural) workforce, are largely forgotten. In socio-political and economic measures and policymaking usually urban women are considered, and the views related to rural women, mainly concentrate around the "deprivation" perspective.

From geographical view, In the province of Gilan - in the North of Iran- the climate is very humid, this makes it possible to grow rice in abundance. Along with rice, there are other cultivated items, such as tobacco, citrus fruits and tea. As a result of this natural environment the local population of Gilan are highly involved in agricultural activities. The women of this province are among the most active and involved in the agriculture sector in the country of Iran (about 29. 7\% according to 2006 National census). Also, the rate of economic participation among women varies from place to place. Surveys have shown that the Central and Western regions of the country have the lowest rates of women's participation in the labour market. Meanwhile most of the rural women's work remains outside the cash sector, which so far has exclude them from active population in the national census. It should be consider that, according to the official statistics, women who work on family farms are also considered as housewives. So the multiple women's roles in their various economic activities and social responsibilities need to be assessed more precisely, particularly because of previous neglect of this information. This article seeks to provide such a base of knowledge on the work of women in rural Gilan in North of Iran. It also indicates how social and economic changes due to development effect on the women's work and their situation in these rural areas.

\section{Literature Review}

The subject of "women and Development" has invited a good deal of attention, especially in the case of rural women, in recent years and rightly so. The overwhelming majority of women workers in rural areas are affected by problems of poverty, unemployment and underemployment. To support economic development and to increase the status of women, it is essential that women, who already have responsibility in issues of production, education, health, family relationships, and nutrition among others, participate in development (Gulcubuk, Bulent, 2010, 143). The following summary of relevant literature is an attempt to synthesize research findings from a wide range of sources.

\subsection{Women's participation and rural development}

Women's labour force participation is a fascinating issue for both theoretical and policy reasons.

Rural economies, particularly those dependent on agriculture, have been affected by the processes of globalisation, leading to the restructuring and decline of the agricultural sector, the growth of the service sector and increased emphasis on technology. In many areas, this has created unprecedented work and employment opportunities, as well as bringing changes in the role and status of women.

Susan Tiano argues that, there are three different attitudes about the impact of the economic development on women: 1) Integration Thesis, According to which development leads to freedom and gender equality. It makes 
women more involved in economic activities. 2) Marginalization Thesis: it argues that with extension of capitalism, women will lose their control upon resources and increasingly, they will depend on men from aspect of their economic needs. 3) Exploitation Thesis: That believes modernization will lead to create Female workforce market with low wages, so they will been exploited, because they are the secondary labour force (Abbot, 1997:97).

Rural women share abundant responsibilities and perform a wide spectrum of duties in running the family, maintaining the household, attending to farm operations, tending domestic animals and engaging in rural artisan work and handicrafts (Rahman 2000). But female labour engaged in such activities is usually not measured in economic terms. An implicit assumption is made that the woman is basically a mother and housewife, any productive work she carries out is considered socially secondary, and thus it has tended to remain unnoticed, more so in the case of rural women Agricultural work, too, is ubiquitous and multifaceted. Poorer women may hire out as agricultural day labourers (A. Sudershan Reddy and H. Girija Rani, 1989:51-57). There is another kind of agricultural labour performed by women is as partners in their family farms, where women are entrusted primarily with the tasks of managing and caring for livestock, raising poultry, assisting in the harvest, and processing plant and animal products for consumption, home utilization or sale. Marketing of the products may be done by either sex. In general, women market poultry and dairy products and small quantities of grain, men market livestock, large quantities of grain and export crops; fruit and vegetable production may be marketed by either sex. These kind of agricultural labour and marketing services are not recorded in formal government statistics, yet they make a significant contribution to family income (Lobban and Richard. 1998, P151Boserup 1970, Dadvar-Khani, 2011). However it should be mention that women's participation in production, the nature of their work and the division of labour between the sexes can then be viewed as a result of women's reproductive functions, and conditioned by the nature of the productive process and by the requirements of a given pattern of growth and accumulation. (International Labour Office Geneva, 1980, 11).

Although steps have been taken to reorient support towards subsistence farmers, many programmes fail to take account of the activities and priorities of women farmers. Initiatives that would benefit women often do not reach them (FAO1995). Clearly, the extension of development's advantages in rural area alone will not guarantee that women are better served and benefited. Also Evenson in his research shows that when a proper accounting of the economic value of all work is undertaken, women contribute more in family income than men, because they work more (Evenson 1985, 23, Saikia 2004). McDonald-Safai, presents data from her research study on the dynamics of work, education, age, among other factors (McDonaldSafai 1991). These are examined within the context of a redefinition of women's contribution to agricultural production in Amlash (one of the townships of Gilan province). she found that virtually none of the women interviewed were literate, yet these women saw the value of education.

Despite the costs from a production sense, the women encouraged their children to attend school (McDonald-Safai 1991 and Dadvar-Khani, 1996).

\section{2 The examination of agricultural factors on women's work}

Agriculture is an enterprise that often engages resources from all family members. These resources include land, labour, and capital. Agriculture is unique in the way it combines the factors of production and, thus, unique in the kind of commitment demanded from family members when they are the source 
of these factors. The role of women in agriculture -just as the role of men in agriculture -can best be understood through an analysis of the relationship or use right; to labour through provision of labour at key times and for key elements in the production cycle; and to capital, in terms of both the mobilization of inputs and the allocation of the surplus produced (Mann and Dickinson 1978, 466-81 SOFA Team and Cheryl Doss 2011).

There is widespread agreement that even though wider processes of agricultural and rural restructuring in the West have led to changes in gender relations, farmwomen are still marginalised from agricultural production (Barthez, 1986: Berlan- Darque and Gasson, 1991;Buttel and Gillepsie; 1984; Brandth 1995; Servaes, J. 1999, Whatmore 1991, SOFA Team and Cheryl Doss 2011). Since then, a growing body of work has analysed the ways in which patriarchal ideologies shape unequal gender relations and identities in farming families in different countries (Saugeres, L; 2002:373-384, ElWaheshy Biri, Brian F. Pendleton and T. Neal Garland, 2002:129-144).

Also easonal situation cause that in some cases use of labour is more economic than use of technology(Frances J 1985, 83). Yet even in these enterprises, family labour is a crucial element for survival for small and middle sized producers.

Generally the first activities to be mechanized in rice production are land preparation, threshing and milling. Transplanting and harvesting, women's traditional tasks, are mechanized at a much later stage of development. As wages in the industrial sector rose in Japan, farm household men and children shifted to off-farm employment, leaving older women to cultivate rice (Ishikawa 1981). Complete mechanization of Japanese rice farming came about only in the 1970s, and women were then able to spend more time in off the farm employment (International rice research institute 1985, 18).
Another important factor that effect women's participation is family income. Jeanne Frances, in the study on rural women in the Philippine argues that the estimates of the contribution of working wives to family earnings suggest the following points. Women from poorer families (in Gatbo) tended to affect family earnings more dramatically than those from less poor households (in Ayugan).

The researcher added that to a poor family, the woman's contribution could have spelled the second or third full meal for the members; to a less poor household, the wives ", earning might have allowed an additional viand per day if not for each of the three meals during the day (Frances 1985, 83).

\subsection{Trends in women's participation in agriculture and rural development in Iran}

Iran is no exception to the gender division of labour which characterises rural communities throughout the world. Women carry out the bulk of domestic and agricultural duties, while men are responsible for specific spheres of activity, such as herding and marketing livestock, ploughing fields, or constructing homes. Men are more likely to allocate or share specific tasks with others, or take on tasks that utilise higher levels of technology.

In contrast, women are more likely to be engaged in the actual work itself. As in most other societies, Iranian women have primary responsibility for housework and child care. They are the ones who clean, cook, bake, do laundry, process food for home consumption, and so on.

These required activities are not considered "work" in the formal sense, and nowhere in the

world are they incorporated into government statistics. They are nevertheless time-consuming tasks that are essential to the maintenance, reproduction, and well- being of the family.

Sometimes the women make food for farm workers to reduce from the expense of production. 
Children share in domestic and agricultural tasks while still young, but soon get tracked into gender-based divisions as they grow older.

In rice cultivation, some kind of division of tasks between sexes has occurred. Women generally do transplanting, weeding and in some places harvesting too, and men ploughing, making bunds, or spraying chemical fertilizer and pesticides. This form of work division can also be recognized in India (Saradamoni 1991), Iran (Dadvar-Khani 1996), Bangladesh, Malaysia, Japan and South Korea (International Rice Research Institute 1985). In the area under study rice is the basic food crop. For households which produce more rice than they consume it is both an exchange crop and a cash crop. As such it represents the main trading and survival commodity in the economy of the area. In rice farming in Iran we do observe the predominance of family farms in rice production. In this area, family labour, especially women's labour has been particularly important in the Northern and other parts of the country.

In this region "transplanting" is called "Zananeh Kari" which means women's duty. This segregation became pale in the Eastern side of the province and is vanishing in province of Mazandaran.

Further, before large mechanization and the relative enterprise specialization that accompanied it, family labour was crucial not only in production for the market but also in producing for subsistence, allowing for cash savings through provision of food and agricultural inputs such as draught power. But because of mechanization and other aspects of rural development this situation is changing dramatically (Dadvar Khani and Ahmadi 2009). Also the research finding show that despite of mechanization of the rice cultivation, in the studied area women's labour has not been replaced with machine in transplantation, because of quality, accuracy and preciseness of women's work.
So, The rapid decrease in employment in agriculture in Iran has resulted in a decrease in employed women as well.

\section{Research Methods}

This research is based on analytical method The data has been gathered by fieldwork carried out in rural areas in the province of Gilan. This area has a humid subtropical climate with a large margin the heaviest rainfall in Iran: reaching as high as 1, 900 millimetres (75 in) in the southwestern coast and generally around 1, 400 millimeters (55 in). It has 13 townships that 7 of them have been chosen due to their rice cultivation domination.

There are 741 villages and they have 108682 households. For this research a sample population of 113 villages and 131 households was chosen randomly.

Data was collected over a sixty day period. This was divided into two portions. The first thirty days was spent collecting data and conducting interviews in the off farm period. Each woman was interviewed on her own, and without the presence of any male guardians.

This research used a 245 item questionnaire. A further interview was conducted focusing on

how the women dedicated and divided their time on a daily basis. The validity of the questionnaire has been examined and approved by Alpha Cronbach method, and received a reliability rating of $84 \%$.

The aim of this research is to analyse the range of impacts, both positive and negative, of rural development on women's participation in agricultural labour force market in rural Gilan.

As household access to social and economic resources increases, combined with increase in

social status, there are naturally a number of changes happening in women's work. The primary result observed was that the physical and psychological burden of labour intensive farming on women was removed. 


\section{Discussion:}

This research seeks to shed light on a number of social and economic issues and realities in the

life of rural women working in the agricultural labour force.

As it has discussed earlier in this paper, rural development accompanied with number of changes in different aspect of rural communities, such as changing in land ownership, increasing in family income and increasing in education. Unexpectedly the evidence indicates that these positive changes led to negative effect on economic and social activity of women.

The following discussion is going to show these relations.

4. 1 The Role of Education \& Literacy Programs in Women's Work:

One of the most important factors that affect women's work is female education in rural areas (As it has indicated in National Statistic of I. R. I the rate of literacy in 1956 was about $10 \%$ but it has increased to $69 \%$ in 2006 (http://www. noormags. com/view/fa/articlepage/93503).

Educational programme in Iran build functional literacy skills can improve women's agricultural outcomes and develop women's selfesteem and confidence - crucial components of sustainable development programme. At the same time the educated female especially whom gain the higher level of education have less tendency to work on agricultural field or in the related activities, which are subsistence and labour intensive works. As it has been mentioned rural women have less access to innovation in agriculture sector, for example the agricultural mechanization is almost men dominated.

So In the absence of non-agriculture jobs, the rate of unemployment for women will increase.

Table 2: Women's education and their Employment

\begin{tabular}{|c|c|c|c|c|c|c|c|}
\hline \multirow[t]{2}{*}{ Education Levels } & \multicolumn{2}{|c|}{$\begin{array}{l}\text { Women's Population } \\
\text { Over } 15 \text { years }\end{array}$} & \multicolumn{3}{|c|}{$\begin{array}{l}\text { Employed population } \\
\text { in agriculture }\end{array}$} & \multirow[t]{2}{*}{$\begin{array}{l}\text { Not Employed } \\
\text { in Agriculture }\end{array}$} & \multirow{2}{*}{$\begin{array}{c}\text { Unemployed } \\
\text { Women's Population } \\
\text { Over } 15 \text { years }\end{array}$} \\
\hline & Number & Percentage & $\begin{array}{l}\text { Wage } \\
\text { workers }\end{array}$ & $\begin{array}{c}\text { Barter } \\
\text { workers }\end{array}$ & $\begin{array}{l}\text { Family } \\
\text { workers }\end{array}$ & & \\
\hline Illiterate & 85 & 34.7 & 18 & 32 & 74 & 9 & 10.6 \\
\hline Elementary & 75 & 30.6 & 10 & 25 & 50 & 23 & 30.6 \\
\hline Secondary & 5 & 2 & 3 & 4 & 20 & 28 & 56 \\
\hline High School & 51 & 21 & 0 & 2 & 5 & 44 & 86 \\
\hline $\begin{array}{c}\text { Diploma } \\
\text { Associate Degree }\end{array}$ & 1 & 0.41 & 0 & 0 & 0 & 1 & 100 \\
\hline $\begin{array}{c}\text { Undergraduate } \\
\text { and higher }\end{array}$ & 3 & 1.22 & 0 & 0 & 0 & 3 & 100 \\
\hline Total & 245 & $89.93^{*}$ & 31 & 63 & 149 & 108 & 44.1 \\
\hline
\end{tabular}

$\mathrm{R}=0.449 \mathrm{~S}=0.000$

$10.7 \%$ missing data 
The distribution of various types of women's work on the basis of their education is shown in

Table 1. As this table demonstrates, there is a strong, meaningful, and inverse relationship between women's work in agriculture and their education. The more education a woman has, the less likely she is to participate in agricultural labour. According to the data $44.1 \%$ of all women over 15 years of age are not engaged in agricultural work. Among those surveyed none with more than a high school education worked in any agricultural field.

The effect of increased education is most visible for women who work to wage jobs sector. However, those women who considered as family workers, even with increased education, continue to work in agriculture to some degree.

The development process leads to increased access to education for both men and women. But the complexity of the relationship between education and employment must be taken into account. In the absence of alternative nonagricultural jobs, the labour market will be unable to accommodate this growing population of educated women.

because more educated women are less likely to work as agricultural labourers, as this kind of work does not carry any cultural value or social prestige. Also the extension of nuclear family may affect on women's work and limit the younger educated mothers to have access to labour market outside of their village.

\subsection{The Effect of Land Ownership Structures on Women's Economic Participation:}

According to the Ministry of Agriculture in Iran, in the majority of farmlands except the smallest (less than 1 hectare) and the largest (more than 100 hectares) agriculture is the primary job of the male head of the household. In these families women's labour force are used as unpaid workers. Within these families, the primary unpaid labourer are the female partners, but in the off school season, children of various ages help their family in the field as well.

In the other hand the development of agriculture is defined as a modernization and mechanization of cultivation practices (RoySingha 1995, 11). The data suggests that men have far more access to these facilities than women. This results in the women continuing to work non-mechanized and low output lands. As our research shows no woman works with machines on the land.

Because the land is the most important thing in the household, control over it is very significant in the defining of the status of family. While the research has indicated that wealth and an increase in property ownership of family has negative impacts on women's work in agriculture sector in rural areas. For example in high class families women have less participation in family labour force and they never work as paid worker in others land. Meanwhile the rate of women's land ownership of this families was extremely rare. This research also shows that when women are resigned from their previous duties in the agricultural field, their capacity as a marketer and economic decision maker in the family will decrease.

Meanwhile those rural women, who families do not own agricultural land, carry out the role of paid labourers on the lands of other farmers. Although, this relationship exists for men to some degree, but it appears in entirely different form. For example, he is now responsible for hiring workers to carry out the work on the land, while still remaining present and in charge. So it can be concluded, that while the same processes of development do occur, their impacts are entirely different based upon gender. 
Table 3: Women's Work Status on the Base on Land Ownership Structure

\begin{tabular}{|c|c|c|c|c|c|}
\hline \multirow{2}{*}{$\begin{array}{c}\text { Land Size } \\
\text { (hectares) }\end{array}$} & $\begin{array}{c}\text { Percentage of Families } \\
\text { with at least One } \\
\text { Woman Labourer }\end{array}$ & $\begin{array}{c}\text { Percentage of Those } \\
\text { Employed in the Total } \\
\text { Population }\end{array}$ & $\begin{array}{c}\text { Percentage of Those } \\
\text { Employed in } \\
\text { Population Over 15 } \\
\text { years }\end{array}$ & \multicolumn{2}{|c|}{$\begin{array}{c}\text { Percentage of } \\
\text { Unemployed within the } \\
\text { Population Over 15 years }\end{array}$} \\
\cline { 3 - 6 } & 75 & 50 & 87.5 & 12.5 & 0 \\
\hline Landless & 70 & 76 & 86 & 10.2 & 3.6 \\
\hline $0.1-0.5$ & 37 & 57.6 & 81.4 & 13.5 & 5 \\
\hline $1.1-2.0$ & 50 & 63 & 81.6 & 10.5 & 9 \\
\hline $2.1-4.0$ & 33 & 65.6 & 66.6 & 16.6 & 10.6 \\
\hline $4+$ & 50 & 38.7 & & & 16.6 \\
\hline
\end{tabular}

${ }^{*}$ All the data collected for the this table is derived from field research.

** It must be noted that women who worked as unpaid laborers on their own land and women who worked to prepare food for laborers on their land have not been indicated on this table.

As it has shown in the table, research participants were divided into seven groups according to land ownership. First: those without land, who are living in conditions of poverty. This group mostly works on the others' land as paid labourers. Second, marginal farmers, who own 1 hectare of land and less. Third, the middle class farmers, who can be divided into two categories, those who own 0.6 -- 1 hectares and those who own 1. 1 - 2 hectares of land. Fourth, those considered as high class farmers, who own 2. 1 -- 4 hectares of land. Finally, those who are considered as prosperous farmers, who own more than 4 hectares of rice cultivation land. On the basis of land ownership distribution among the participants the majority fell into the middle class category. From among these 56\% owned between $0.6-1$ hectares of land and $27 \%$ owned 1. 1 - 2 hectares of land. This group constituted $83 \%$ of the sample households. Only 4 families owned more than 4 hectares of land. The category of high class farmers as a whole made up $11 \%$ of the research samples. The remaining $6 \%$ included the families in the lowest class (either marginal or landless families), all these lands are considered as intensive cultivation lands.

It should be mentioned that the average of rice production in the area is $3250 \mathrm{Kg}$ per hectare. If the average of rice price be $\$ 1.5$ per $\mathrm{kg}$, then the average of the family income from rice cultivation will be about $4875 \$$.

This table shows that, in landless families, at least $75 \%$ of these households have at least one woman who works in agriculture. From the population over 50 years old $87.5 \%$ are employed. Indeed, 12. 5\% of the unemployed population is women. The primary reasons for this is that men have more mobility and are able to find job out of their village or to have access to non-agricultural work.

The highest rate of unemployed women is among the high class farmers (4+ hectares of land).

Also we can see the same rate of unemployment for males. Due to the labour intensive and physically strenuous nature of agricultural work, when the family income increases these families prefer to replace the family labour with paid workers. The children withdrew from labour market to attend in schools and universities.

Indeed due to scattered cultivation lands and their limitation in size, there are not enough works for all family members. Meanwhile, in the work season, some rural areas attract labourers from other places.

A majority of these workers are women who's related to landless or poor rural families.

The table (3) shows that there is an inverse relationship between the size of the land owned 
and the women's work. It means that when land ownership increases, it results in more economic advantages in rural families and it reduces the number of women engaged in the agricultural labour force.

This relationship is highlighted particularly in wage and barter workers. This particular type of work forms a kind of "labour brokerage", in that a group of brokers, collect the women from different villages, early in the morning during the peak season, and then distribute them in the cultivation fields. For the service that they give to women, they usually request $10-20 \%$ of women's salary per day.

The data indicates that women who fall in the category of high class farmers $(4+$ hectares of land) almost never participate in the labour market as agricultural paid workers, though they do in fact continue to work in their own homes and their farm. An important point is that women of poor landless families still have low rates of work - and there is little opportunity to work as family or exchange worker for their neighbours because, owning land is necessary for both types of works so they are looking for alternative jobs in paid labour market. The women of high class farming families are less engaged in farming, husbandry, and chicken breeding.

In the other hand it can discuss that women in poor and middle class families save their families from falling below the poverty line in two ways: First, they work directly in farm as a family worker, or for wages or as exchange labourer on other's land. Secondly, they help reduce the expense of production and increase the efficiency of the work, for example they prepare meals for workers.

It can be concluded that development has challenges and particular economic implications for women in rural areas. The data shows that among the entire range of women in the rural areas of this study alternative economic activities are also pursued. These ranges from selling eggs in the market, to the production of handicrafts and produce of processed food. They do these activities in order to ease the economic burdens and improve the situation of their families.

\subsection{The Relationship between Family Income \& Women's Works:}

The data from this study shows that the primary reason for women to work in this rural area stems from economic needs. It shows that when income of family increases due to farm extension or increasing in agricultural production and even through remittances of migrant member of the family, it is women who exclude from farm works And due to limitations in accessing to non- agricultural works they remain unemployment.

Indeed in an economic crisis not only women unable to obtain access to employment opportunities, but many lose their previous works. In some cases, it was observed they offered their jobs to unemployed male member of their families.

Table 4: The Percentage of Men and Women's Income and Their Participation in Agricultural Production per Month

\begin{tabular}{|c|c|c|c|c|c|}
\hline Gender & $\begin{array}{c}\text { Total } \\
\text { income }\end{array}$ & Numbers & $\begin{array}{c}\text { Average } \\
\text { Income }\end{array}$ & $\begin{array}{c}\text { Percentage of participation in } \\
\text { agriculture* }\end{array}$ & $\begin{array}{c}\text { The portion of family's income } \\
\text { earned }\end{array}$ \\
\hline Male & 36682000 & 156 & 235141 & 63.3 & $91 \%$ \\
\hline Female & 3756300 & 49 & 766592 & 36.7 & $9 \%$ \\
\hline Total & 40438300 & 205 & 197260 & 100 & 100 \\
\hline
\end{tabular}

$\mathrm{R}=-0.183 \mathrm{~S}=0.004$ [total in last line does not agree across the line -- workers counted $=351$ ] 
* The percentage of participation of men and women in agricultural work is on the basis of time and duty allocation in agricultural work.

* The data in this table is measured in Iranian Rials and is based upon fieldwork in area understudy. (One Dollar equals about 9220 Rials. (in Oct. 8th 2010).

As Table 4 indicates, there are 156 men in comparison with 49 women whose income is derived from agricultural or non-agricultural work. There is a large gap between the incomes earned by each sexes. The average income for men is 316964 Rials more than the average income for women. Part of this discrepancy is due to the fact that the income that is generated from family and exchange labourer is considered to be part of the man's income. It can be observed that while women constitute 36.7 of the labour force, they only receive $9 \%$ of the income.

\section{Conclusion}

As rural areas continue to develop, a number of changes occur in the social, economic, and cultural dimensions in agriculture sector. In developing nations, women have a major role in agricultural work. Poorer women may be hired out as agricultural day labourers. Meanwhile development policy in rural areas and increasing in family's income led to exclusion of female member of family from agricultural labour market, also mechanization of cultivation can accelerate the situation. The participation of women in the rural labour market is more critical when they are the head of the family (Yusef and Hetter, 1980).

The unequal division of power, access to resources, and duties, according to gender, are

institutionalized by local traditions. The research showed that there is strong relationship between social and economic changes in the process of development, such as increased family income, higher education, and more extensive land ownership, reduce the women work on field and replace them with paid labour or machines. So women who are working on their families' field or on the fields of others as paid worker may lose their work. By ignoring women, programs led to push women out of traditional productive roles. It can offer some more free time to women but it turns them into a consumer position. So the increase in family wealth and greater access to education for these women means that women's participation in agricultural labour will decrease.

This is in accordance with the Marginalization Thesis of Tiano. It means that in the absence of appropriate development programs; these women will face economic isolation. This situation will further support the idea of the "housewife"- The idea that women belong solely in the private sphere. If such a situation continues, in the absence of suitable job opportunities, the women's capacity and potential shall not be fulfilled in the future. To introduce suitable development strategies, there is a need for "gender sensitive" projects, which can address the different effects of development projects on women and men. These projects should focus on women directly and must recognize the real ability and needs of these modern rural women.

\section{References}

Abbott, Pamela. Wallace. CLR. (1997) Introduction to feminist approaches in sociology, Translated in Persian by Maryam Khorasani \& Ahmad Ahmadi, Mother Publication, Iran, Tehran, P 97.

Adelman, Irma Glicma and C. T Morris. 1973. Economic growth and social equality in developing Countries. Stanford Univ. 1973 257pp, figs, dw.

Ahmad, Aminah. 1998. Country Briefing Paper on women in Malaysia 3: women"s 
participation in economic Development. www. adb. org/Documents/Books/country Briefing papers/.

Bani Hashem, and Forough El Sadat. 1997. Rural Women \& the Need for Formation of Economic Institutions, Payam e Zan No. 20: (In Persian).

Barthez, A. (1986) Du labeur paysan au métier d'agriculteur: l'élaboration statistique en agriculture. Cah. Econ. Sociol. Rurales 3, 4572.

Berlan-Darque and Gasson, (1991) Women in Agriculture special issue, Journal of Rural Studies, 7 (1991) Nos $1 / 2$.

Rae Lesser Blumberg(2005) Women's Economic Empowerment as the "Magic Potion" of Development? Paper presented at the 100th Annual Meeting of the American Sociological Association, Philadelphia.

Boserup, Ester. 1970. Women's Role in Economic Development, London: Allen and Unwin.

Brandth 1995; Rural masculinity in transition, gender images in tractor advertisement, Journal of rural studies, 11, 123-133.

Buttel Frederick H, and Gilbert W. Gillespie; Jr (1984) The sexual division of farm household labour an exploratory study of the structure of on-farm and off-farm labour allocation among farm men and women "Rural Sociology 49:183-209.

Carr, M., Chen, M. and Jhalovala R. (eds). (1996). Speaking out women's Economic Empowerment in South Asia, London, Intermediate Technology Publications.

Cornelia B. Flora (1985) Women and Agriculture, Agriculture and Human Values - Winter.

Dadvar Khani Fazileh and Ahmadi (2009) The analysis of factors affected on Socio-Economic

Decision -making of women within households in rural areas. Case study of Zanjan Township in Iran. (In Persian).

Dadvar-Khani Fazileh (1996) The Status \& Role of Women's Work in the Process of Rural Development: A Case Study of Gilan-Iran. $\mathrm{PhD}$ thesis, University of Tarbiyat Modarres, Iran. (In Persian).
Dadvar-Khani Fazileh (2012) Participation of rural community and tourism development in Iran, Journal of Community Development, Rutledge 43:2, 259-27,

http://dx. doi. org/10. 1080/15575330. 2011. 604423.

Dadvar-Khani Fazileh \& Farshad Soory (2011) Gender approach in the analysis of villagers' satisfaction with the performance of the Rural local managers: (A Case Study of Koohdasht township in Iran.

Dauber, R. S cain, M. ceds(1981)Women and technological change in Developing countries. Boulder: Westview press, ins.

Debal K. Singha Roy(1995) Women, New technology and development, changing nature of Gender relations in rural India, Manohar, India.

Ellen Sue, M. Chalton (1984) Women in third world development, Westview press, Boulder and London.

El-Waheshy Biri, Brian F. Pendleton and T. Neal Garland (2002) Correlates of men's attitudes toward women's roles in Libya, International Journal of Sociology of the Family; Autumn91, Vol. 21 Issue 2, p129-144.

Evenson, Robert (1985) in International Rice Research Institute, Women in rice farming.

Frances, Jeanne. 1985. Wives at work, Patterns of labour force participation in two rice farming villages in the Philippines in: International rice research institute: 83

Henshall Momsen, Janet(2004) Gender and Development, London and New York: Rutledge.

Ignatius A. Madu (2010) Patterns in the Nsukka Region of South-eastern Nigeria, Journal of Rural and Community Development, Case Study The Underlying Factors of Rural Development, Department of Geography, University of Nigeria, Nsukka, ISSN: 17128277 www. jrcd. ca

Inglehart, Ronald (1997) Modernisation and post modernisation, Cultural, Economic and political change in 43 societies. 
International Labour Office Geneva (1980) Women in Rural Development, Critical Issues: 11.

International Rice Research Institute(1985) Women in Rice Farming: 14.

Ishikawa, Shigeru(1981) Essays on Technology, Employment and Institution in Economic Development: Comparative Asian Experience, Economic Research Series No. 19, Tokyo.

Gulcubuk, Bulent (2010) The Dimensions Of Women's Contribution To The Workforce In Agriculture:The Turkey Case, International Business \& Economics Research Journal, Volume 9, Number 5

Kongolo, M. and Bamgose, O. O. (2002). Participation of Rural Women in Development: A Case Study of Tsheseng, Thintwa, and Makhalaneng Villages, South Africa. Journal of International Women's Studies, 4(1), 79-92.

Maneja, Claire Aster(2002) Women weaving and the web:an Analysis of Rural Indian women's Economic Agency in Attaining economic empowerment, master of Arts thesis in communication, culture and technology, Washington, D. C.

Mann, Susan A. and Dickinson, James M. (1978) Obstacles to the Development of a Capitalist Agriculture. Journal of Peasant Studies, 5: 466-481

McDonald- Safai, Marcia (1991) A Redefinition of women's contribution to agricultural production in Amlash, Iran., International Journal of Sociology of the Family; 21(1): pp. 17-37; Spring 1991, 21p. Lucknow Publishing House ; India.

Nussbum, Martha C. (2002) Women and Human development, The capabilities approach. Kali for Women, New Delhi, India.

Pyakuryal, Kiran(2001) Strengthening IncomeGenerating opportunities for Rural women in Kazakhstan, Bangkok, Thailand, p. 5.

Raeesi, Soheila (2008) The Evolution of Rural Women's Participation in Iran, In Transition to Industrial Society, In Conference on Women's Participation \& Agricultural 1400,
Volume 1, The Institute of Planning \& Economy of Agriculture. (In Persian).

Rahman, Sanzidur(2000) Women's employment in Bangladesh agriculture: Composition, determinants and scope, 2, 3 Source: Journal of Rural Studies, v 16, n 4, p 497-507.

Roy, Debal K. Singha. \& Centre for Women's Development Studies(1995) Women, new technology and development: changing nature of gender relations in rural India / Debal K. Singha Roy Manohar, New Delhi.

Saikia, Anuva(2004) Employment patterns of rural women and their involvement in decision-making: A study in Jorhat District of Assam, Indian Journal of Agricultural Economics, v 59, n 1 SUPPL., p 44-53, January/March2004.

Saradamoni, K(1991) Filling the Rice bowl, Women in Paddy Cultivation.

Saugeres, L. (2002) The cultural representation of the farming landscape: masculinity, power and nature, Journal of rural Studies ; 2002, 18(4):373-384, Great Britain.

Scarlett. T, Epstin, Rosemary A. Watts (1981) The endless day, some case material on Asian rural women. Women development Series Vol. 3.

Sen, A. (1999) Development as freedom. Oxford: Oxford University Press.

Servaes, J (1999) Communication for development: One world, multiple cultures, Cresskill, New statistical center of Iran (2006) Statistic of population and settlements.

Staudt, Kathleen (1978) Agricultural Productivity Gaps: a Case Study of Male Preference in

Government Policy Implementation in Development and Change 9(3).

Stiglitz, J. (2002)Participation and development: Perspectives from the comprehensive development paradigm. Review of Development Economics, 6(2), 163-182.

Unnevehr L. J. \& M. L. Stanford (1985) Technology and the demand for women"s labour in Asian rice farming Women in rice farming, International rice research Institute. 
Whatmore, S(1991)Life cycle or patriarchy? Gender divisions in family farming, Journal of Rural Studies, 7 (1991), pp. 71-76

Yusef and Hetter (1980) Women in rural development, Critical issues, International Labour Office Geneva. 